\title{
Do conservative media provide a forum for skeptical voices? The link between ideology and the coverage of climate change in British, German, and Swiss newspapers
}

\author{
Hannah Schmid-Petri \\ University of Bern \\ Institute of Communication and Media Studies \\ Fabrikstrasse 8 \\ 3012 Bern, Switzerland \\ email: Hannah.Schmid-Petri@ikmb.unibe.ch, \\ phone: +41-(0)31-631-3847
}

Funding: This publication was created in the context of the Research Unit "Political

Communication in the Online World" (1381), subproject 7, which is funded by the DFG, German Research Foundation. The subproject is also funded by the Swiss National Science Foundation (SNF, 100017E-135915).

\begin{abstract}
:
This study analyzes whether the ideological orientation of a newspaper has an influence on the salience of skeptical arguments (trend, attribution, impact, and response skeptics) in the coverage of climate change in the UK, Germany, and Switzerland, and examines whether certain newspaper titles act as advocates of the skeptical countermovement. A quantitative content analysis of a broad newspaper sample for each country over the course of one year (June 2012-May 2013) was conducted. The results reveal that conservative newspapers do not amplify skeptical voices in general; the difference between conservative and more liberal outlets is only found in the case of impact and response skepticism. Second, in each country, certain conservative newspapers are particularly open to skeptical arguments.
\end{abstract}

Keywords: print media coverage, climate change, skeptics, ideology, content analysis

Note: This manuscript is accepted for publication in Environmental Communication. 


\section{Do conservative media provide a forum for skeptical voices? The link between ideology and the coverage of climate change in British, German, and Swiss newspapers}

A substantial body of research exists that analyzes how climate change is presented in various media types and in different countries (e.g., Boykoff \& Mansfield, 2008; Dispensa \& Brulle, 2003; Painter \& Gavin, 2015; Gavin \& Marshall, 2011; Grundmann \& Scott, 2014; Painter \& Ashe, 2012; Kaiser \& Rhomberg, 2015). However, we still do not know much about the factors explaining the way how the issue is portrayed - especially which mechanisms are responsible for a high number of skeptical voices in particular coverage.

One explanation for the occurrence of skeptical arguments is the journalists' adherence to the norm of balance, i.e. the journalists aim to cover both sides of an issue, which results in an over-representation of skeptical viewpoints in the coverage (known as "balance of bias," Boykoff \& Boykoff, 2004). Although this was a characteristic of the coverage in the past, more recent studies could no longer find balanced coverage, at least in UK and US print media (Boykoff, 2007; Xie, 2015; Schmid-Petri et al., 2015).

In addition to the effects of balanced reporting, another factor seems to account for the presence of skeptical arguments in print media articles: the ideological leanings of the newspaper. In particular the work of Dunlap and McCright (2008; 2010; 2011) has shown that conservative ideology is linked to the denial of global warming and the human contribution, or to the questioning of possible negative impacts. This link is also reflected in the coverage of climate change in conservative newspapers - previous research has shown that they act as amplifiers of skepticism. However, most studies in the field focus on the UK (Carvalho, 2007; Carvalho \& Burgess, 2005; Ereaut \& Segnit, 2006; Painter \& Gavin, 2015); research including other countries is rare and provides mixed results (Dirikx \& Gelders, 2010; Kaiser \& Rhomberg, 
2015; Schmid-Petri et al., 2015). Dirikx and Gelders (2010), for example, find a link between ideology and the coverage of climate change in French newspapers but not in Dutch print media.

Thus, this paper extends and widens the focus of previous studies by including data from three different countries: the UK, Germany, and Switzerland. The research question is: Is there a link between the ideological orientation of a newspaper and the salience of skeptics in the coverage?

This general research question is differentiated in two ways. First, we know from previous work that different types of skepticism can be distinguished, for example: trend, attribution, impact skeptics and response skeptics (Capstick \& Pidgeon, 2014; Rahmstorf, 2004). But previous studies analyzing the link between the ideological orientation of a newspaper and the salience of skeptics in the coverage did not differentiate their measurement or their results between these types of skepticism; thus, we do not yet know if the ideological orientation plays a more central role for a certain type of skepticism. Therefore, the second research question is: What is the link between the ideological orientation of a newspaper and the salience of different types of skeptics in the coverage?

Second, the study aims to deepen the analysis and gain further insights as to whether specific conservative newspaper outlets lead the way in disseminating skeptical arguments. Thus, the third research question is: Are there specific conservative newspapers who act as advocates of the countermovement?

The contribution of the study is threefold. First, it extends and broadens previous research. The inclusion of the UK allows previous studies (Painter \& Ashe, 2012; Painter \& Gavin, 2015; Boykoff \& Mansfield, 2008) to be replicated and continued with more recent empirical data (June 2012 to May 2013). Furthermore, Germany and Switzerland are added to the sample - for these countries, a comprehensive study analyzing the link between the ideological orientation of a newspaper and the salience of skeptical arguments in the reporting 
is still missing. Germany and Switzerland are especially interesting, as the relation between newspapers and political parties is historically high, as it is in the UK. Therefore, it is plausible to assume that the newspapers favor a specific ideological worldview. But we still do not know if this orientation is also visible in the way climate change is presented. Second, the study deepens the understanding of the link between ideology and newspaper reporting by dismantling the ideological orientation for different types of skepticism. Third, the study includes a broad sample of newspapers for each country, which allows for a more explorative analysis of the role specific newspapers play in emphasizing skepticism.

Given that climate change and its impacts are some of the most urgent global challenges, it is important to understand and to gain better insight into factors that explain a specific type of coverage, as this reporting may create a climate of opinion which facilitates or hinders political action (Baumgartner \& Jones, 1993).

The paper is structured as follows. First, the ideological leaning of a newspaper as an explanatory factor for the presence of skeptical arguments is discussed and differentiated according the different types of skepticism. Afterwards, I describe the logic of the content analysis. The third section presents the results. The paper finally closes with a wider discussion of the role the ideological leanings of a newspaper play in climate change media coverage.

\section{Ideological leanings as explanatory factor for the presence of skeptical arguments}

According to Carvalho (2007, p. 225), an ideology is "a system of values, norms and political preferences, linked to a program of action vis-à-vis a given social and political order” (see also Freeden, 2013). As the media is an inherent part of society, it follows that reporting is embedded in certain world views. Carvalho (2005, p. 225) describes the relation between media discourse and ideology as "mutually constitutive: media output is not only a product of an 
ideological standpoint, but media-output in itself also reproduces or even challenges ideologies." Thus, it can be assumed that many media outlets follow a certain ideology corresponding with the basic political orientations - a phenomenon that Hallin and Mancini label political parallelism (2004). According to Hallin and Mancini (2004), Germany and Switzerland belong to the Democratic Corporatist Model with a high level of political parallelism in the press. Great Britain belongs to the liberal model, which is theoretically characterized by a low level of political parallelism. However, Hallin and Mancini (2004) themselves emphasize that the UK is an atypical case within the liberal model because the UK print media system shows a high level of political parallelism. Correspondingly, in the more recent classification of media systems developed by Brüggemann et al. (2014), the UK, Germany, and Switzerland all belong to the central model (named according to the geographical location of the countries belonging to this type). Thus, according to this classification, the UK, Germany, and Switzerland have comparable levels of political parallelism, which falls in the middle compared to other types of media systems (p. 1054). Thus, it is plausible to assume that the selected countries do not differ much in the role the ideological orientation of a newspaper plays in its coverage of skeptical voices.

Skepticism towards climate change is "an imprecise term that has multiple meanings given the complex multi-faceted nature of the climate debate” (Poortinga, et al., 2011, p. 1016). In the literature there exist several different classifications of skeptics (e.g. Capstick \& Pidgeon, 2014; Rahmstorf, 2004; Hobson \& Niemeyer, 2012; Howarth \& Sharman, 2015; Van Rensburg, 2015; see also Washington \& Cook, 2011). Generally two broad categories of skepticism can be distinguished: First, skepticism concerning the scientific evidence of climate change and second, skepticism regarding responses to address climate change or processes of decision making or communication (Capstick \& Pidgeon, 2014; Van Rensburg, 2015). For the differentiation of skepticism towards the scientific evidence Rahmstorf (2004) distinguishes between trend, attribution and impact skeptics: 
The first type, trend skeptics (Rahmstorf, 2004) or deep skeptics (Hobson \& Niemeyer, 2012), deny that global warming is happening. Attribution (Rahmstorf, 2004) or causal skeptics (Hobson \& Niemeyer, 2012), as a second type, reject the anthropogenic causes of climate change or question whether there is enough evidence to identify the causes. These two types are more fundamental forms of climate skepticism (Schmid-Petri et al., 2015). The third type of skepticism, labeled impact skepticism by Rahmstorf (2004) and Hobson and Niemeyer (2012), deny neither the trend nor the human causes of global warming, but claim that the consequences of climate change are positive. In contrast, response or policy skepticism does not focus on the validity of scientific evidence but claims that no binding regulations to limit global warming are needed, as regulations would harm the free market and would negatively impact the national economy (Capstick \& Pidgeon, 2014; Van Rensburg, 2015).

Impact and response skepticism are more concealed forms of denial, as they do not question global warming per se nor the human contribution to it.

Surveys among the public revealed that these different types of skepticism often do not exist separately from each other but are closely related in the minds of the respondents (Capstick, 2010; Poortinga et al., 2011). However, for media coverage, several previous studies have shown that different types of skepticism appear in British and American newspaper coverage (Painter \& Ashe, 2012; Painter \& Gavin, 2015; Boykoff \& Boykoff, 2004; Boykoff, 2007; Schmid-Petri et al., 2015). Thus, the categorization seems useful to systematize and disentangle the various arguments applied by skeptics and is used as basis for this study as well. But of course it is plausible to assume that the different types of skeptical arguments are linked to one another and may appear together, for example in the case that an actor speaking within a newspaper article mentions arguments belonging to different types of skepticism at the same time. 
On a general level, especially conservative political values are strongly linked to skepticism (Dunlap \& McCright, 2008; 2010; McCright \& Dunlap, 2000) as any kind of environmental protection includes government action and this contradicts the core values of conservatism. Any regulations for example to curb carbon dioxin emissions "are seen as a direct threat to sustained economic growth, the free market, national sovereignty, and the continued abolition of governmental regulations - key goals promoted by the conservative movement.” (McCright \& Dunlap, 2000, p. 505)

Concerning the importance of ideological leanings in covering the different types of skepticism mentioned above, existing studies offer initial insights. With regard to trend skepticism, the studies of Carvalho (2007) and Ereaut and Segnit (2006) show that liberal media outlets in the UK emphasize that global warming is happening, whereas conservative newspaper often portray the occurrence of climate change as uncertain (Carvalho, 2007; Ereaut \& Segnit, 2006). As Germany and Switzerland belong to the same type of media system as the UK (Brüggemann et al., 2014), one can assume:

H1a: Conservative newspapers in the UK, Germany, and Switzerland publish more articles containing trend skepticism compared to liberal media.

Until now, no study has examined how ideological orientation influences the coverage of attribution or impact skepticism. Only Kaiser and Rhomberg (2015), in studying German coverage, observe that the conservative newspaper Die Welt mainly discusses the causes of climate change. As the denial of the human contribution to climate change is the central argument used by attribution skeptics this could be interpreted as a first hint that conservative newspapers focus more on this type of skepticism than liberal media.. Combined with the fact that the three nations are similar in terms of other types of skepticism, hypothesis $1 \mathrm{~b}$ and $1 \mathrm{c}$ state: 
H1b: Conservative newspapers in the UK, Germany, and Switzerland publish more articles containing attribution skepticism compared to liberal media.

H1c: Conservative newspapers in the UK, Germany, and Switzerland publish more articles containing impact skepticism compared to liberal media.

Furthermore, there is empirical evidence that this difference also holds true for response skepticism, in the sense that more left-leaning newspapers focus on the need for urgent action to combat global warming. On the contrary, conservative newspapers oppose binding policy regulations and/or argue for continuing with existing policy regulations (Carvalho, 2005; Carvalho \& Burgess, 2005; Ereaut \& Segnit, 2006):

H1d: Conservative newspapers in the UK, Germany, and Switzerland publish more articles containing response skepticism compared to liberal media.

The link between conservative political values and skepticism towards climate change is also shown in surveys among the public. For the UK Poortinga et al. (2011) for example reveal that especially older individuals who are politically conservative hold skeptical views (see also Whitmarsh, 2011). Metag, Füchslin and Schäfer (2015) find similar results for Germany.

In addition to the mere appearance of skeptical voices, the following question arises: through which mechanisms do skeptical arguments enter the mass media debate? One mechanism identified in previous studies is that skeptical arguments are mainly emphasized in opinion-based articles, namely in commentaries, editorials, or op-eds (Elsasser \& Dunlap, 2013; Painter \& Ashe, 2012; Painter \& Gavin, 2015). In these types of articles, editors or single journalists have the freedom to publish their own opinion or to invite special guest commentators. Therefore, it is plausible to assume that the ideological leaning of a newspaper (and, correspondingly, a distinct editorial stance on a topic) can mainly be found in opinionbased articles. Hypotheses 2a to 2d state: 
H2a: Conservative newspapers in the UK, Germany, and Switzerland publish more opinion-based articles containing trend skepticism than fact-based articles containing trend skepticism.

H2b: Conservative newspapers in the UK, Germany, and Switzerland publish more opinion-based articles containing attribution skepticism than fact-based articles containing attribution skepticism.

H2c: Conservative newspapers in the UK, Germany, and Switzerland publish more opinion-based articles containing impact skepticism than fact-based articles containing impact skepticism.

H2d: Conservative newspapers in the UK, Germany, and Switzerland publish more opinion-based articles containing response skepticism than fact-based articles containing impact skepticism.

With regard to how different newspaper titles handle skeptical arguments, previous work reveals in the UK, that the conservative Times (Carvalho, 2005, 2007, Carvalho \& Burgess, 2005), The Telegraph, the Daily Express, and the Daily Mail publish the most articles containing skeptical arguments (Boykoff \& Mansfield, 2008; Painter \& Gavin, 2015). For Germany, Kaiser and Rhomberg (2015) show that the most skeptical outlet is the conservative daily Die Welt, concerning the coverage of the COP 17 in Durban 2011. For Switzerland, no study currently exists analyzing the amount of skeptical voices in different newspapers.

Overall, the results suggest that specific newspapers in each country act as particular amplifiers of skeptical arguments. However, the studies of Carvalho $(2005,2007)$ and Carvalho and Burgess (2005) are limited in this regard, in that they focus on the UK and include only the coverage of three newspapers between 1985 and 2000. The more recent study of Painter and Gavin (2015) extends this research and covers three different periods between 2007 and 2011. 
Furthermore, they include a broad sample of all 10 main UK dailies and their Sunday editions. Nevertheless, this study only includes the UK. Thus, there is no recent study including a broad sample of newspapers in several countries. Therefore, it is not clear if the mentioned newspaper titles still act as advocates of the countermovement or if the picture has changed. Thus, the first research question is:

RQ1: Are there specific conservative newspapers who act as advocates of the countermovement?

\section{Methods and Measurement}

\section{Sample}

To answer the research question, a quantitative content analysis was conducted. For Germany and the UK, the sample included the most important daily and weekly newspapers and magazines in terms of nationwide circulations and their opinion-leading role in the discussion about climate change. For Switzerland, we included the German-language outlets fulfilling the mentioned criteria for the German-speaking part of Switzerland (see table 1 for more detailed information about the sample). The sample period included one year of coverage, from June 1, 2012 to May 31, 2013. The aim was to choose a period which represents today’s typical debate about climate change in German, British and Swiss print media and where no special events (e.g. natural disasters) took place which could have influenced the type of coverage.

To draw a national sample of relevant articles, we first used the Factiva and LexisNexis search engines to identify all articles containing the key words "climate change" or "global warming" 1 somewhere in the full text (for our study only articles published in the print-outlets

\footnotetext{
${ }^{1}$ A pretest of different keyword combinations revealed that searching for "climate change" OR "global warming" identified all relevant articles discussing our topic.
} 
of the relevant newspapers and magazines were included) ${ }^{2}$. For the news magazine GEO and the weekly newspaper WOZ, the articles were searched manually following the same procedure. Next, we drew for Germany and for the UK a random monthly sample of 35 articles each, resulting in 420 articles for each over the study period of one year ${ }^{3}$. In Switzerland, only 285 articles overall were published during our sample period. Thus, for Switzerland, all articles are added to the sample for coding. An article became part of our sample if one of the keywords was mentioned somewhere in the article and if the article included at least one actor-argument sequence, that is, an actor putting forward at least a problem definition on the issue and additionally a cause, a consequence, or a treatment recommendation (see below) to ensure that the included articles really contained relevant information about the topic.

\section{Classification of newspapers according to their ideological leaning}

To be able to answer the research questions, we divided the newspapers into different groups according to their ideological leanings (table 1):

- UK: We primarily followed previous research on climate change (Painter \& Gavin, 2015) and the work of Wring and Deacon (2010), who classified the most important print media in the UK according to their endorsements for the national election; therefore, most newspapers (and their Sunday editions) of our sample could be classified. The relatively new newspaper $i$ belongs to The Independent and can be characterized as a line-extension of The Independent - described as “a cut-price, cutdown version of the full-price, full-size The Independent that maintained the excellence of its editorial content” (Hatfield, 2011). Therefore, it was classified, along with The

\footnotetext{
2 This resulted in a population of 2197 articles for Germany and 4729 articles for the UK.

${ }^{3}$ To draw a random monthly sample we created a list of all articles containing one of the keywords, assigned an automatically generated random number to each article (using the function provided by Excel), sorted the list by these random numbers and finally assigned the first 35 articles to our sample which included at least one actorargument-sequence.
} 
Independent, as left-leaning/liberal. Another Sunday newspaper, The People (now named Sunday People), was also not classified in previous literature. The People belongs to the Mirror Group and endorsed the Labour Party in the last election (Nelson, 2015). Thus, it was also classified as left-leaning/liberal. The Star, which was also part of our sample, can be described best as populist and sensationalist (Painter \& Gavin, 2015) and does not clearly support a political ideology. Therefore, we excluded all articles from The Star from further analysis $(n=2)$.

- Germany: The German media outlets were classified following Maurer and Reinemann (2006, pp.129-130). They subsume several previous studies that tried to identify the ideological leaning of a newspaper by analyzing endorsements for specific candidates (Brettschneider, 2002; Lüter, 2004) or by studying the position of distinct media outlets that were in conflict (Kemner, Scherer \& Weinacht, 2008). For the economic journal Handelsblatt and for the environmental magazine GEO, which were also part of our sample (Handelsblatt $n=18$, GEO $n=7$ ), no classification could be found. Therefore, they are excluded from further analysis.

- Switzerland: For Switzerland, the newspapers were also classified based on work of Blum (2004) and Vontobel (2005) (see also Künzler, 2013, pp. 169-171). One magazine in our sample, Der Beobachter, could not be classified; we therefore excluded these articles from the analysis $(n=2)$.

[please insert table 1 about here] 


\section{Measuring skepticism}

The coding to measure the number of skeptical voices for each article took place on two levels. First, on the article level, we coded several formal variables and up to the three most important actors (MIAs), where actor importance was defined by the space that was devoted to their statements. Thereby we applied a broad understanding of actors to capture all relevant statements within an article. Thus, actors could be individual speakers as well as collective actors who advance their view of the issue in the document or used descriptions which point clearly to an individual (e.g. "he”, "she”) or a group of speakers (e.g. "skeptics argue that”) or an institution. An exception with regard to the above given definition was the journalist/author of the article: He/she also could be a MIA if he/she acts as a speaker in the text giving his/her own interpretation of the issue for example in opinion pieces. Second, on the actor level, we coded several variables regarding the content of statements of the identified MIAs. This actorargument sequence contained variables on the actors' problem definition of climate change (belief or denial that climate change is occurring) and whether they referred to human and natural causes of climate change, positive and negative consequences, and/or proposed treatment recommendations.

The measurement of skepticism is based on previous work (Schmid-Petri et al., 2015; Boykoff \& Boykoff, 2004; Painter \& Gavin, 2015). In contrast to previous studies, impact and response skepticism are measured separately and not grouped together to one type of skeptical arguments. This measurements follows the above mentioned definition which distinguishes between skepticism regarding the scientific evidence (trend, attribution and impact skepticism) and skepticism towards responses to combat global warming which is not directly based on scientific evidence. The four types of skepticism were defined as follows:

- Trend skepticism: The measurement of trend skepticism includes articles in which at least one MIA expresses the opinion that climate change is not happening. 
- Attribution skepticism: Articles containing attribution skepticism are articles in which at least one MIA dismisses anthropogenic causes or mentions natural causes.

- Impact skepticism: This type of skepticism is found in articles where at least one MIA has the view that global warming has positive consequences.

- Response skepticism: For measuring response skepticism articles are included in which at least one MIA states that action to address climate change is not necessary or should not be mandatory.

All types were coded on the level of the actors who expressed them in an article. To be able to compare the results to former studies, the data was then, in a second step, aggregated to the article level. Six trained coders completed the coding. Krippendorff's Alpha for the variables on the article level was .84 and on the actor level .74 (see Appendix A for detailed reliability scores).

\section{Results}

With regard to the influence of ideological leanings, hypotheses $1 \mathrm{a}-1 \mathrm{~d}$ state that the conservative newspapers are amplifiers of different types of skeptical arguments.

Concerning trend and attribution skeptics ( $\mathrm{H} 1 \mathrm{a}$ and $\mathrm{H} 1 \mathrm{~b})$, the results reveal no differences between more liberal/left-leaning and more conservative/right-leaning newspapers (table 2). Conservative newspapers did not cover more arguments containing trend or attribution skeptics. This result is stable across all countries under study. Thus, hypotheses 1a and $1 \mathrm{~b}$ must be rejected. These results correspond with the findings of Dirikx and Gelders (2010) who found for Dutch and French newspapers also no difference between left- and rightleaning newspapers in their coverage of trend skepticism. 


\section{[please insert table 2 about here] $]^{4}$}

The findings emerge as expected only, at least in the tendency, for impact and response skepticism (H1c-d). Thus, the conservative/right-leaning newspapers especially focus on the following arguments: global warming has positive consequences, no action is needed to combat climate change or regulations should at least not be mandatory.. This pattern can be seen for all the three countries. Thus, hypotheses $1 \mathrm{c}$ and $1 \mathrm{~d}$ are supported by the empirical data. Dirikx and Gelders (2010) find a similar pattern for France in the way that conservative newspapers covered more often arguments containing response skepticism. No such difference was found in their study between the left- and right-leaning newspapers in the Netherlands.

Hypotheses $2 \mathrm{a}$ to $2 \mathrm{~d}$ state that conservative newspapers in the UK, Germany, and Switzerland publish more opinion-based articles containing trend, attribution, impact or response skepticism than fact-based articles with skeptical arguments. Table 3 shows that this assumption is true for articles containing trend or attribution skepticism: The comparison between news and opinion pieces reveals that these two types of skepticism are more prevalent in opinion-based articles. This pattern is seen in all three countries. Thus, hypotheses $2 \mathrm{a}$ and $2 \mathrm{~b}$ are supported by the data. For impact and response skepticism, however, the picture changes: With regard to response skepticism there are no differences between news and opinion pieces. The salience of impact skepticism is even higher in news reporting than in commentaries or editorials. Hypotheses 2c and 2d are therefore rejected.

In relation to the results displayed in table 2, we see that impact and response skepticism seem to be a specific characteristic of the conservative press and appear in the reporting as well as in opinion pieces and editorials. For the UK, compared to former studies, the importance of

\footnotetext{
${ }^{4}$ As table 2 shows there is an overlap between different types of skepticism, as in some articles different skeptical arguments are mentioned together. However, on the level of a single actor voicing his/her opinion within an article we see that the different types are neatly separated: Only 12 actors out of 563 actors speaking in the Swiss newspaper articles mention several types of skeptical arguments together, followed by 11 actors (out of 776) in the British newspapers and 9 actors (out of 736) in German newspaper articles.
} 
attribution skepticism has diminished over time. Painter and Ashe (2012) found in their study for the British press also hardly any trend skeptics but attribution skeptics have the highest salience compared to the other types of skeptical messages. Our results show that if these forms of skepticism appear at all, they appear mainly in opinion-based articles of conservative newspapers.

\section{[please insert table 3 about here]}

The first research question asks if there are some newspapers that act as advocates of the countermovement, meaning that they especially write in favor of skeptical viewpoints and thus are especially responsible for a high level of skepticism. For this more explorative analysis, we considered all newspapers that had at least 10 articles in our sample. For Switzerland, the results show that the conservative weekly magazine, Die Weltwoche, published the most articles containing skeptical voices compared to the other newspapers. There were overall 26 articles in Die Weltwoche, of which 14 (54\%) mention skeptical arguments. Only two of these articles are purely skeptical; thus, the skeptical views are uncontested. All other skeptical articles also contain arguments from climate change advocates.

In Germany, the newspaper Die Welt together with its Sunday edition, Welt am Sonntag, contains the greatest number of skeptical articles (21 out of 49: 43 percent). Out of these, 11 articles give room to purely skeptical views (52\%). This corresponds with the results of Kaiser and Rhomberg (2015), who also identify Die Welt as especially likely to publish skeptical arguments.

In the UK, skeptical articles primarily appear in two tabloids, Daily/Sunday Express (8 out of 22: 36 percent) and Daily/Sunday Mail (7 out of 19: 37 percent). The Daily/Sunday Telegraph is third-highest, with 17 skeptical articles out of 36 (32\%). Thus, compared to the previous studies of Painter and Gavin (2015) and Boykoff and Mansfield (2008), the picture has not changed. They also identify these three newspapers as amplifiers of skeptical opinions. 
The Daily/Sunday Mail produces the most uncontested, purely skeptical articles (5 out of 7), whereas in the Daily/Sunday Express (3 out of 8) and the Daily/Sunday Telegraph (8 out of 17), the number of undisputed skeptical arguments is lower.

Hence, concerning the first research question, the results show that there are certain newspapers that act as advocates of the countermovement. Interestingly, all these newspapers are right-leaning/conservative outlets. Thus, although the link between the ideological leaning and the type of coverage about climate change can only be seen for impact and response skepticism on the level of the single newspapers, there is evidence that the conservative ones in particular support skeptical arguments. However, the results displayed in table 2 do not change even when the specific newspapers acting as advocates of the countermovement are filtered out. ${ }^{5}$ Thus, ideological orientation seems to influence how climate change is portrayed more generally, at least for impact and response skepticism; it is not only specific outlets that amplify exclusively skeptical voices.

\section{Discussion}

Concerning the link between the ideological orientation of a newspaper and the salience of skeptics in the reporting, the results show on a general level that conservative newspapers do not especially emphasize trend or attribution skepticism. Thus, the coverage of these types of skepticism is not influenced by the ideological leaning of a newspaper. But a relationship is seen in the case of impact and response skepticism - conservative newspapers are more likely to publish arguments containing impact and response skepticism than are liberal outlets. This pattern is seen in all countries $(\mathrm{UK}, \mathrm{D}, \mathrm{CH})$ that were part of this study.

\footnotetext{
${ }^{5}$ For Switzerland: Die Weltwoche; for Germany: Die Welt and Die Welt on Sunday; for the UK: Daily/Sunday Express and Daily/Sunday Mail.
} 
An explanation for the high salience of response skepticism in conservative newspapers could be that this type of skepticism best suits the conservative ideology: response skeptics doubt the need for binding regulations, are against interventions in the free market, and thus fear that political treaties among greenhouse gas emitters worldwide could have negative consequences for the economy. Additionally, impact skeptics emphasize the potential positive economic consequences of global warming (for example, in the tourism industry). The result is what Painter and Gavin (2015, p. 15) describe as an "ideological antipathy of some right-leaning editors and proprietors toward the sort of solutions proposed to the climate challenge, which often involve strong state intervention in the economy.”

Second, we see that trend and attribution skepticism in particular appears in opinion pieces or commentaries of conservative newspapers, whereas impact skepticism occurs mostly in news reporting of conservative outlets and articles containing response skepticism are evenly spread between news and opinion pieces. Thus, the more fundamental forms of skepticism find their niche in article types that explicitly include the stance of the editors or of a single journalist. Impact and response skepticism, on the contrary, seem to have reached a high level of social acceptance that it has become part of the standard news reporting about climate change. Thus, the discourse about climate change seems to have changed over time: Nowadays, it is difficult to question the occurrence of global warming (trend skepticism) or the anthropogenic contribution to it (attribution skepticism), as the scientific consensus about these basic assumptions has strengthened over time. Now, skeptics primarily question the need for binding regulations (response skepticism) or emphasize positive consequences global warming might have (impact skepticism). Impact skepticism has also strengthened in American print media coverage (Schmid-Petri et al., 2015). By highlighting impact and response skepticism, the coverage, especially in the conservative newspapers, communicates the impression that no binding regulations are needed, thus creating a climate of opinion that may hinder efforts to combat global warming. Especially these cognitive effects of media coverage about climate 
change have been shown in previous research. Although media are less powerful to change concrete climate-related behavior they are important and trusted sources of information about the phenomenon and are able to raise the knowledge and awareness concerning global warming (Schäfer, 2015).

Third, in every country, certain newspaper titles act as advocates of the countermovement and are especially prone to publish skeptical arguments. These conservative newspapers support the notion that there is a link between the ideological orientation of a newspaper and the way the newspaper portrays climate change. Thus, we see that the publisher or the editors of a newspaper can play a crucial role in how an issue is portrayed. In Switzerland, for example, the conservative weekly magazine Die Weltwoche is an amplifier of skeptical voices. The chief editor of the magazine, Roger Köppel, was also a candidate in the Swiss national elections in autumn 2015 for the national conservative party, Swiss People’s Party (SVP). Die Weltwoche openly pursues an editorial stance supporting the positions of the Swiss People's Party. The party states in a position paper that they are against a climate or energy tax (SVP, 2015) and that the causes and effects of climate change are still uncertain (Killer, 2009). Thus, following the idea of a high level of press-party parallelism, as described by Hallin and Mancini (2004), this close relationship between the magazine and the right-wing party explains the comparably high number of skeptical arguments published in the magazine. For the other countries, the relation between a specific conservative party and the newspapers is not as close as in Switzerland (apart from a shared conservative ideology).

Fourth, the structure and the degree of competition of the press market can drive the publication of skeptical arguments. In the UK, for example, the two newspapers with the highest salience of skeptical voices are tabloids. Highlighting skeptical arguments can be a unique selling point and a strategy to distinguish the newspapers from competitors. Additionally, 
skeptical arguments can be used to pronounce conflict (e.g., within politics or the scientific community) and thus to generate attention.

Overall the results show that the whole amount of skeptical voices seems to have increased over time: Painter and Gavin (2015) found in their study 20 per cent of the articles containing skeptical voices in British newspapers for November 2010 until February 2011 compared to an overall amount of 25 per cent of articles with skeptics in our study. For Germany Kaiser and Rhomberg (2015) reveal skepticism in 15 per cent of the articles (during four weeks around the COP conference in Durban). This amount increased to 29 per cent in our study. For Switzerland so far no comparable research exists. In our study we find a comparable high amount of 33 per cent of articles covering skeptical arguments.

From theoretical and methodological perspectives, the results reveal that it is important to distinguish between different types of skepticism. In doing so, changes in the discourse emerge, as do varying patterns of influence of a media outlet's ideological leanings, which otherwise would not have been detected. Our study focused on the most prominent categorization of different types of skepticism which was originally developed by Rahmstorf (2004) and which is widely used in social science research. However, there are of course other possibilities to group skeptical arguments (for an overview see for example Howarth \& Sharman, 2015; Van Rensburg, 2015). Especially arguments that focus on the process of scientific knowledge generation or on the uncertainty of the timing, scale and location of impacts are not included in our study but are of course important arguments of the skeptical discourse. Further studies should consider these types of skepticism as well - especially to be able to capture changes over time in the structure of skeptical argumentations.

Additionally this form of labelling opinions is not unproblematic as such a classification fails to represent nuances or viewpoints that are positioned between the extremes. Thus, the categorization itself may advance a polarization of the debate (Howarth \& Sharman, 2015). 
Our study also has shown that the different types of skepticism sometimes appear within the same newspaper article but are only very rarely mentioned together by an actor speaking within an article. Thus, in contrast to other results based on surveys (e.g. Poortinga et al., 2011) the different skeptical arguments are, at least within newspaper coverage, neatly separated. This could be explained by journalistic working and writing routines: As journalists normally aim to write clearly formulated and well understandable articles they may try to avoid a mixture of several different, although related, arguments.

A limitation of the study is that only newspapers are analyzed. It seems plausible to assume that trend and attribution skeptics are still more salient in online communication due to its low barriers to entry and the relative ease of publishing. Furthermore, it would be useful to include more countries to see how the discourse about climate change is structured elsewhere, and to determine if a relation between the ideological orientation and the coverage of climate change exists. Additionally, the analysis of advocacy in the context of this study is explorative. For further research it would be interesting to go into more detail and to get deeper insights into the concrete mechanisms which lead to such an advocacy, for example if there are single journalists who favor skeptical arguments or if mainly external sources (as opportune witnesses, Hagen, 1993) are cited to support skeptical views.

Overall, the results of this study show that newspapers are embedded in broader ideological world views, which are reflected in the way a specific issue is portrayed in media coverage. For instance, we found that conservative newspapers do provide a forum for skeptical voices, and that there is a link between ideology and the coverage of climate change in British, German, and Swiss newspaper. This link is differentiated in two ways. First, it is dependent on the type of skepticism; second, on the type of article (news vs. opinion pieces); and third, on the specific conservative news outlet. 


\section{References}

Baumgartner, F.R. \& Jones, B.D. (1993). Agendas and instability in American politics. Chicago: University of Chicago Press.

Boykoff, M.T. (2007). Flogging a dead norm? Newspaper coverage of anthropogenic climate change in the United States and United Kingdom from 2003 to 2006. Area, 39(4), 470481.

Boykoff, M. T. \& Boykoff, J. M. (2004). Balance as bias: global warming and the US prestige press. Global Environmental Change, 14, 125-136.

Boykoff, M. T., \& Mansfield, M. (2008). 'Ye Olde Hot Aire': reporting on human contributions to climate change in the UK tabloid press. Environmental Research Letters, 3, 1-8.

Blum, R. (2004). Mehrheit links der Mitte. Medienprofessor Roger Blum stuft erstmals die 34 wichtigsten Print- und elektronischen Medien in einem Links-rechts-Schema ein. Facts, 04/30. Available online: http://www.andreasladner.ch/dokumente/artikel/Facts_04_30.pfd.pdf [2015/10/17].

Brettschneider, F. (2002). Kanzlerkandidaten im Fernsehen. Häufigkeit - Tendenz Schwerpunkte. Media Perspektiven, 263-276.

Brüggemann, M., Engesser, S., Büchel, F., Humprecht, E., \& Castro, L. (2014). Hallin and Mancini Revisited: Four Empirical Types of Western Media Systems. Journal of Communication, 64(6), 1037-1065.

Capstick, S. B. \& Pidgeon, N. F. (2014). What is climate change scepticism? Examination of the concept using a mixed methods study of the UK public. Global Environmental Change, 24, 369-401.

Carvalho, A. (2007). Ideological cultures and media discourses on scientific knowledge: rereading news on climate change. Public Understanding of Science, 16(2), 223-243.

Carvalho, A. (2005). Representing the politics of the greenhouse effect: Discursive strategies in the British media. Critical Discourse Studies, 2(1), 1-29.

Carvalho, A., \& Burgess, J. (2005). Cultural Circuits of Climate Change in U.K. Broadsheet Newspapers, 1985-2003. Risk Analysis, 25(6), 1457-1469.

Dirikx, A. \& Gelders, D. (2010). Ideologies overruled? An explorative study of the link between ideology and climate change reporting in Dutch and French newspapers. Environmental Communication, 4, 190-205. 
Dispensa, J. M. \& Brulle, R. J. (2003). Media's social construction of environmental issues: Focus on global warming - a comparative study. International Journal of Sociology and Social Policy, 23(10), 74-105.

Dunlap, R. E. \& McCright, A. M. (2008). A widening gap: Republican and Democratic views on climate change. Environment: Science and Policy for Sustainable Development, 50(5), 26-35.

Dunlap, R. E. \& McCright, A. M. (2010). Climate change denial: sources, actors and strategies. In C. Lever-Tracey (Ed.), Routledge Handbook of Climate Change and Society (pp. 240-259). New York: Routledge.

Dunlap, R. E. \& McCright, A. M. (2011). Organized climate change denial. In J. S. Dryzek, R. B. Norgaard, \& D. Schlossberg (Eds.), The Oxford Handbook of Climate Change and Society (pp. 144-160). Oxford: Oxford University Press.

Elsasser, S. W. \& Dunlap, R. E. (2013). Leading voices in the denier choir: Conservative columnists' dismissal of global warming and denigration of climate science. American Behavioral Scientist, 57(6), 754-776.

Ereaut, G. \& Segnit, N. (2006). Warm words. How are we telling the climate story and can we tell it better? Available online: http://www.climateaccess.org/sites/default/files/Ereaut\%20\&\%20Segnit_Warm\%20W ords.pdf [2015/10/17].

Freeden, M. (2013). Ideology. In G. Claeys (Eds.), Encyclopedia of modern political thought (pp. 419-423). Thousand Oaks: Sage Publications.

Gavin, N. T. \& Marshall, T. (2011). Mediated climate change in Britain: Scepticism on the web and on television around Copenhagen. Global Environmental Change, 21(3), 1035-1044.

Grundmann, R. \& Scott, M. (2014). Disputed climate science in the media: Do countries matter? Public Understanding of Science, 23(2), 220-235.

Hagen, L. (1993). Opportune Witnesses: An Analysis of Balance in the Selection of Sources and Arguments in the Leading German Newspapers' Coverage of the Census Issue. European Journal of Communication, 8, 317-343.

Hallin, D.C. \& Mancini, P. (2004). Comparing media systems: Three models of media and politics. Cambridge: Cambridge University Press.

Hatfield, S. (26.10.2011). Everything you wanted to know about i... and asked! Available online: http://www.independent.co.uk/news/media/press/everything-you-wanted-toknow-about-i-and-asked-6254076.html [2015/10/05]. 
Hobson, K. \& Niemeyer, S. (2012). "What sceptics believe": The effects of information and deliberation on climate change scepticism. Public Understanding of Science, 22(4), 396-412.

Howarth, C. C. \& Sharman, A. G. (2015). Labeling opinions in the climate debate: a critical review. WIREs Clim Change, 6, 239-254.

Kaiser, J. \& Rhomberg, M. (2015). Questioning the Doubt: Climate Skepticism in German Newspaper Reporting on COP17. Environmental Communication, DOI:10.1080/17524032.2015.1050435

Kemner, B., Scherer, H. \& Weinacht, S. (2008). Unter der Tarnkappe. Der Einsatz „volatiler Themen“ und „opportuner Zeugen“ in der Berichterstattung zum Übernahmeversuch der ProSiebenSat.1 Media AG durch den Springer-Verlag. Publizistik, 53(1), 65-84.

Killer, H. (2009). Klimatologische Veränderungen der letzten Jahre und weitere Entwicklung. Available online: https://www.svp.ch/aktuell/referate/klimatologischeveraenderungen-der-letzten-jahre-und-weitere-entwicklung/ [2015/10/27].

Künzler, M. (2013). Mediensystem Schweiz. Konstanz: UVK Verlagsgesellschaft.

Lüter, A. (2004). Politische Profilbildung jenseits der Parteien? Redaktionelle Linien in Kommentaren deutscher Qualitätszeitungen. In C. Eilders, F. Neidhardt \& B. Pfetsch (eds.), Die Stimme der Medien. Pressekommentare und politische Öffentlichkeit in der Bundesrepublik (pp. 167-195). Wiesbaden: VS.

Maurer, M. \& Reinemann, C. (2006). Medieninhalte. Eine Einführung. Wiesbaden: VS Springer.

McCright, A. \& Dunlap, R. E. (2000). Challenging global warming as a social problem: An analysis of the conservative movement's counter-claims. Social Problems, 47(4), 499522.

Metag, J., Füchslin, T. \& Schäfer, M. (2015). Global warming’s five Germanys: A typology of Germans، views on climate change and patterns of media use and information. Public Understanding of Science, 1-18.

Nelson, N. (2015). The Sunday People endorses Ed Miliband to be the next prime minister of the UK. Available online: http://www.mirror.co.uk/news/uk-news/sunday-peopleendorses-ed-miliband-5626595 [2015/10/27].

Poortinga, W., Spence, A., Whitmarsh, L., Capstick, S \& Pidgeon, N. F. (2011). Uncertain climate: An investigation into public scepticism about anthropogenic climate change. Global Environmental Change, 21, 1015-1024. 
Painter, J. \& Ashe, T. (2012). Cross-national comparison of the presence of climate scepticism in the print media in six countries, 2007-10. Environmental Research Letters, 7(4), 1-8.

Painter, J., \& Gavin, N. T. (2015). Climate Skepticism in British Newspapers, 2007-2011. Environmental Communication, 1-21. doi:10.1080/17524032.2014.995193

Rahmstorf, S. (2004). The climate sceptics. Available online: http://www.pikpotsdam.de/ stefan/Publications/Other/rahmstorf_climate_sceptics_2004.pdf [2015/10/27].

Schäfer, M. (2015). Climate change and the media. In Neil J. Smelser and Paul B. Baltes (Eds.), International Encyclopedia of the Social and Behavioral Sciences (2nd edition), 853-859.

Schmid-Petri, H., Adam, S., Schmucki, I. \& Häussler, T. (2015, online first). A changing climate of skepticism? The factors shaping climate change coverage in the US press. Public Understanding of Science. Online first, DOI: 10.1177/0963662515612276

SVP (06/09/2015). Verfassungsbestimmung für ein Klima- und Energielenkungssystem. Available online: https://www.svp.ch/positionen/vernehmlassungen/verfassungsbestimmung-fuer-einklima-und-energielenkungssystem/ [10/27/2015].

van Rensburg, W. (2015). Climate change scepticism: A conceptual re-evaluation. SAGE Open, April-June 2015, 1-13.

Vontobel, J. (2005). Politische Positionen von Schweizer Qualitätszeitungen. Unveröffentlichte Lizenziatsarbeit Zürich.

Washington, H. \& Cook, J. (2011). Climate change denial. Heads in the sand. London, Washington: Earthscan.

Whitmarsh, L. (2011). Scepticism and uncertainty about climate change: Dimensions, determinants and change over time. Global Environmental Change, 21, 690-700.

Wring, D. \& Deacon, D. (2010). Patterns of Press Partisanship in the 2010 General Election. British Politics, 5(4), 436-454.

Xie, L. (2015). The story of two big chimneys: A frame analysis of climate change in US and Chinese newspapers. Journal of Intercultural Communication Research, 44(2), 151177. 
Appendix A: Detailed reliability scores for the variables

1. Agreement concerning the identification of the three most important actors (MIAs): $77 \%$

2. Variables on the document level:

\section{Krippendorff's Alpha}

Type of the article $\quad .84$

$N=30$ documents; each coder was compared separately to a master coding

3. Variables on the actor-argument level:

\section{Krippendorff's Alpha}

\begin{tabular}{ll}
\hline Occurrence of climate change* & .69 \\
\hline Climate change seen as a problem* & .75 \\
\hline Causes of climate change & .75 \\
\hline Consequences of climate change & .76 \\
\hline Treatments & .76
\end{tabular}

$N=30$ commonly identified MIAs; each coder was compared separately to a master coding *Holsti: 92\% for "occurrence of climate change and 94\% for "climate change seen as problem”

(both variables have only four levels)

\section{Appendix B}

Skeptical articles in liberal newspapers news vs. opinion pieces/editorials (\%)

\begin{tabular}{lcc|cc|cc}
\hline & \multicolumn{2}{c|}{ CH } & \multicolumn{2}{c|}{ D } & \multicolumn{2}{c}{ UK } \\
\hline & News & Opinion & News & Opinion & News & Opinion \\
\hline Articles containing ... & & & & & & \\
\hline$\ldots$ trend skeptics* & - & - & 2 & - & 3 & 8 \\
\hline $\begin{array}{l}\ldots \text { attribution } \\
\text { skeptics* }\end{array}$ & 11 & - & 6 & 6 & 4 & 8 \\
\hline$\ldots$ impact skeptics* & 6 & - & 7 & 6 & 3 & - \\
\hline$\ldots$ response skeptics* & 13 & $n=3$ & 11 & 24 & 14 & 16 \\
\hline$\ldots$ no skepticism & 72 & $n=6$ & 76 & 65 & 78 & 75 \\
\hline$N$ & 71 & 9 & 210 & 34 & 148 & 51 \\
\hline
\end{tabular}

*Some articles contain more than one type of skepticism; thus, the sum of the columns exceeds 100 percent in some cases. 
Table 1: Categorization of the newspapers according to their ideological leanings

\begin{tabular}{|c|c|c|c|}
\hline & Left-leaning/Liberal & Centrist & Right-leaning/Conservative \\
\hline \multicolumn{4}{|l|}{ UK } \\
\hline & The Guardian \& The & & The Times \& The Sunday \\
\hline & Observer & & Times \\
\hline & The Independent \& The & & The Telegraph \& The Sunday \\
\hline & $\begin{array}{l}\text { Independent on Sunday \& } \\
i\end{array}$ & & Telegraph \\
\hline & $\begin{array}{l}\text { Daily Mirror \& The } \\
\text { Sunday Mirror }\end{array}$ & & Financial Times \\
\hline & The People (now & & Daily Express \& The Sunday \\
\hline & SundayPeople) & & Express \\
\hline & & & $\begin{array}{l}\text { Daily Mail \& The Mail on } \\
\text { Sunday }\end{array}$ \\
\hline & & & The Sun \\
\hline \multicolumn{4}{|r|}{ 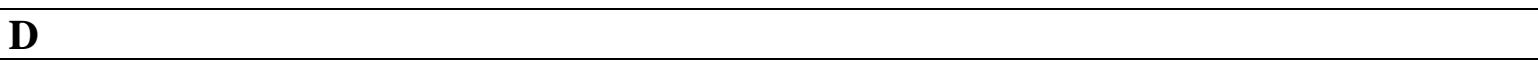 } \\
\hline & Süddeutsche Zeitung & & BILD \& BILD on Sunday \\
\hline & Frankfurter Rundschau & & Die Welt \& Welt on Sunday \\
\hline & Taz & & $\begin{array}{l}\text { Frankfurter Zeitung \& FAZ } \\
\text { on Sunday }\end{array}$ \\
\hline & Der Spiegel & & Der Focus \\
\hline & Der Stern & & Financial Times Deutschland \\
\hline & Die ZEIT & & \\
\hline \multicolumn{4}{|l|}{$\mathbf{C H}$} \\
\hline & $\begin{array}{l}\text { Die Wochenzeitung } \\
\text { (WOZ) }\end{array}$ & Die Sonntagszeitung & $\begin{array}{l}\text { Neue Zürcher Zeitung (NZZ) } \\
\text { \& NZZ on Sunday }\end{array}$ \\
\hline & Der Tagesanzeiger & $\begin{array}{l}\text { Der Blick \& } \\
\text { Sonntagsblick }\end{array}$ & Die Weltwoche \\
\hline
\end{tabular}


Table 2: Skeptical articles in newspapers according their ideological leaning (\%)

\begin{tabular}{lccc|cc|cc}
\hline & \multicolumn{3}{c}{ CH } & \multicolumn{3}{c|}{ D } & \multicolumn{2}{c}{ UK } \\
\hline & Liberal & Centrist & Cons. & Liberal & Cons. & Liberal & Cons. \\
\hline Articles containing .. & & & & & & & \\
\hline$\ldots$ trend skeptics* & 2 & 3 & 4 & 3 & 2 & 5 & 6 \\
\hline $\begin{array}{l}\text {.. attribution } \\
\text { skeptics* }\end{array}$ & 12 & 8 & 10 & 6 & 4 & 5 & 5 \\
\hline$\ldots$ impact skeptics* & 5 & 5 & 8 & 6 & 11 & 2 & 3 \\
\hline$\ldots$ response skeptics* & 15 & 16 & 18 & 14 & 19 & 14 & 18 \\
\hline$\ldots$ no skepticism & 71 & 68 & 64 & 74 & 65 & 77 & 73 \\
\hline$N$ & 85 & 38 & 160 & 271 & 124 & 206 & 212 \\
\hline
\end{tabular}

*Some articles contain more than one type of skepticism, thus the sum of the columns exceeds in some cases 100 percent.

Table 3: Skeptical articles in conservative newspapers: News vs. opinion pieces/editorials $(\%)^{6}$

\begin{tabular}{lcc|cc|cc}
\hline & \multicolumn{2}{c|}{ CH } & \multicolumn{2}{c|}{ D } & \multicolumn{2}{c}{ UK } \\
\hline & News & Opinion & News & Opinion & News & Opinion \\
\hline Articles containing ... & & & & & & \\
\hline$\ldots$ trend skeptics* & 2 & 17 & - & 5 & 4 & 13 \\
\hline $\begin{array}{l}\text {.. attribution } \\
\text { skeptics* }\end{array}$ & 8 & 22 & 3 & 10 & 5 & 9 \\
\hline$\ldots$ impact skeptics* & 10 & - & 11 & 15 & 3 & - \\
\hline$\ldots$ response skeptics* & 17 & 17 & 21 & 20 & 18 & 19 \\
\hline$\ldots$ no skepticism & 66 & 61 & 65 & 60 & 74 & 68 \\
\hline$N$ & 125 & 23 & 95 & 20 & 155 & 47 \\
\hline
\end{tabular}

*Some articles contain more than one type of skepticism; thus, the sum of the columns exceeds 100 percent in some cases.

${ }^{6}$ The distribution for liberal/left-leaning print media is found in Appendix B. 